Agro-Science Journal of Tropical Agriculture, Food, Environment and Extension Volume 17 Number 1 (January 2018) pp. $20-26$

ISSN 1119-7455

\title{
SHORT-TERM EFFECTS OF NPK FERTILIZER AND COCOA POD-BASED MANURES ON SOIL CHEMICAL PROPERTIES, GROWTH AND CUCUMBER YIELD IN GUINEA SAVANNAH
}

\author{
*Dunsin O., Aboyeji C.M., Adekiya A.O., Alade V.O. and Adebiyi O.T.V. \\ Department of Crop \& Soil Sciences, \\ Landmark University, PMB 1001, Omu-Aran,Kwara State, Nigeria \\ *Corresponding author's email: dunsin.oluwagbenga@lmu.edu.ng
}

\begin{abstract}
A field experiment was conducted at the Teaching and Research Farms of Landmark University Omu-Aran, Kwara State of Nigeria, for comparative evaluation of inorganic fertilizer with sole and integrated forms of cocoa pod ash (CPA) and cocoa pod husk powder (CPHP) on soil chemical properties, growth and yield of cucumber in Southern Guinea Savannah Zone of Nigeria. The treatments used for the experiment were control, NPK 20:10:10 (200 kg/ha), $100 \%$ CPA (10 t/ha), $100 \%$ CPHP $(10 \mathrm{t} / \mathrm{ha}), 100 \% \mathrm{CPA}(10 \mathrm{t} / \mathrm{ha})+100$ \% CPHP (10 t/ha), $100 \%$ CPA $(10$ t/ha $)+50 \%$ CPHP (5 t/ha), $50 \%$ CPA + 100\% CPHP, and $50 \%$ CPA + $50 \%$ CPHP. At two weeks after planting NPK 20:10:10 was applied to the assigned plots at the rate of 200 $\mathrm{kg} / \mathrm{ha}$. Treatments were arranged in Randomised Complete Block Design (RCBD), replicated three times. Data collected were subjected to analysis of variance using SPSS procedure while DMRT at 5\% level of probability was used to separate the means. Results showed that treatment with 10 t/ha CPA +10 t/ha CPHP increased soil chemical properties compared to control. Treatments with $100 \%$ CPA $+100 \%$ CPHP and $100 \%$ CPA + 50\% CPHP gave significantly higher and similar values of plant height, number of leaves, number of lateral branches and other yield parameters (fruit number, fruit length, fruit girth, fruit weight and total yield) of cucumber compared to the control. Therefore, the application of $10 \mathrm{t} / \mathrm{ha} \mathrm{CPA}+5 \mathrm{t} / \mathrm{ha}$ CPHP was considered best for growing cucumber in the study area. These cocoa wastes are readily available and eco-friendly compared to NPK that is costly and which may have adverse effect on the environment.
\end{abstract}

Key words: cocoa pod ash, cocoa pod husk powder, cucumber, soil chemical properties, growth and yield

\section{INTRODUCTION}

The aim of a farmer is to improve crop production at minimum cost in order to maximize profit but his major problem is how to maintain soil fertility (Ogbonna, 2008). Soils in Nigeria especially soils of the Southern Guinea Savanna are generally inherently infertile owing to low vegetation cover, soil erosion and low organic matter content occasioned by constant bush fire leading to low organic matter and available nutrients (Eifediyi et al., 2015); hence its productivity and sustainability decline over time when subjected to continuous cultivation. In an attempt to correct these deficiencies, sole application of mineral fertilizers and organic manures are widely practiced. Yet, the fertility of the soil has not been able to sustained optimum crop production that can feed the teaming population as a result of their demerits which can be attributed to is slow release of nutrient in organic fertilizers and faster release of nutrients by inorganic fertilizers, which are often lost rapidly by leaching, high cost and their continuous application acidifies soil (Idem et al., 2012). There is need to source for locally available organic materials that are cheap, environmentally feasible and their complementary effect can give optimum crop productivity and soil fertility maintenance. Nigeria is one of the largest producer of cocoa, which made the availability of the product cheap and commercially available (Wessel \& Quist-Wessel, 2015). There is also a renewed interest in the use of burnt organic residues from plants as sources of phosphate and potash fertilizers (Ayeni, 2008; Ayeni et al., 2008). Ash derived from cocoa pod husk has been found as useful source of both macro and micro nutrients for various crops in Nigeria (Ajayi et al., 2007; Akanbi et al., 2014). Also, Information is abundant on the use of cocoa pod husk as a source of fertilizer for the production of other fruit tree (Adu-Dapaah et al., 1994). Cucumber (Cucumis sativum) is an important 
vegetable and one of the most popular members of the Cucurbitaceae family (Lower and Edwards, 1986; Thoa, 1998). Cucumbers have not received as much press as other vegetables in terms of health benefits, but these widely cultivated food crops provides us with a unique combination of nutrients. At the top of the phytonutrient list for cucumbers are its cucurbitaceous, lignans, and flavonoids. These three types of phytonutrients found in cucumbers provide us with valuable antioxidant, anti-inflammatory, and anti-cancer benefits (Muruganantham et al., 2016). Organic manure play direct role in plant growths as source of all necessary macro and micro nutrients in available forms during mineralization and improving physical and chemical properties of soils (Chaterjee et al., 2005). Continuous application of sole inorganic fertilizer negatively influence the soil organic carbon content by modifying both the $\mathrm{C}$ inputs and losses which influence the soil quality and crop productivity (Follett, 2001).

Bush fallowing has been an efficient, balanced and sustainable agricultural system for soil productivity and fertility restoration in the tropics (Ayoola and Adeniran, 2006), but as a result of increase in the population, the fallowing periods have decreased from ten years to three years and this has had an adverse effect on the fertility restoration leading to poor yields of crops. Therefore, the use of external inputs such as organic manure has become imperative. The aim of this research work are to evaluate the effect of NPK fertilizer with sole and integrated form of cocoa pod ash and cocoa pod powder solely on the chemical properties of the soil, growth and yield of Cucumis sativus L.

\section{MATERIALS AND METHODS Description of Experimental Site and Climatic condition}

The experiment was conducted at Landmark University, Omu-Aran, Kwara state (Latitude $8^{\circ} 8^{\prime}$ $0^{\prime \prime} \mathrm{N}$ and Longitude $5^{\circ} 6^{\prime} 0^{\prime \prime} \mathrm{E}$ ) located at the guinea savannah zone of Nigeria. It has an annual rainfall pattern which extends between the months of April and October with $600 \mathrm{~mm}-1500 \mathrm{~mm}$ with peak rainfall in May-June and September-October while the dry season is between November and March. The experimental site is composed of a texturally laterite soil type which contains high proportion of iron and aluminum as residues.

\section{Sources of Experimental Materials}

Cucumber seeds were gotten from Premier Seed Nigeria Limited, Zaria. The variety selected was Market more. Cocoa pod were gotten from Edidi village, Kwara State through the local farmers. The pods were sun dried and burnt into ash inside a bin.
The ash was sieved to remove pebbles, stones and unburnt shafts. The cocoa pod powder was made by crushing the dried pod in a mill. Both the cocoa pod ash and powder were incorporated into the soil two (2) weeks before planting for mineralization.

\section{Soil Sampling and Laboratory Analysis}

Composite soil sample at plough depth $(0-30 \mathrm{~cm})$ was taken before planting commenced with the aid of steel core samplers. Soil samples were also taken at the end of the experiment on each of the plot. The soil samples were mixed, air-dried, grounded and passed through a $2 \mathrm{~mm}$ sieve before determination. Soil organic matter was analysed using the following methods; organic $\mathrm{C}$ was determined by Walkley and Black sulphuric aciddichromate digestion followed by back titration with ferrous ammonium sulphate (Anderson and Ingram, 1993). Total $\mathrm{N}$ was determined by digesting $0.3 \mathrm{~g}$ of the soil sample in a mixture of $\mathrm{Se}, \mathrm{LiSO}_{4}, \mathrm{H}_{2} \mathrm{O}_{2}$ and concentrated $\mathrm{H}_{2} \mathrm{SO}_{4}$ (Anderson and Ingram, 1993). The $\mathrm{N}$ content in the digest was determined calorimetrically. Available $\mathrm{P}$ was determined by the Olsen method as described by Okalabo et al. (2002). The basic cations (K, Ca and $\mathrm{Mg}$ ) were extracted by leaching $5 \mathrm{~g}$ of soil sample with $50 \mathrm{ml}$ ammonium acetate at $\mathrm{pH} 7$ (Anderson and Ingram, 1993). The exchangeable K in the extract was determined with flame photometer, and $\mathrm{Ca}$ and $\mathrm{Mg}, \mathrm{Fe}, \mathrm{Zn}, \mathrm{Mn}$ and $\mathrm{Cu}$ were determined using an absorption spectrophotometer. Soil $\mathrm{pH}$ was determined using a glass $\mathrm{pH}$ meter at a 1:2 soil / water ratio. Particle size analysis was done using the hydrometer method (Gee and Or, 2002).

About $2 \mathrm{~g}$ subsamples of the cocoa pod ash and powder were analyzed to determine their nutrient composition. The sample was analyzed for organic $\mathrm{C}$, total $\mathrm{N}, \mathrm{P}, \mathrm{K}, \mathrm{Ca}$ and $\mathrm{Mg}$. The percentage organic carbon was determined by the Walkely and Black (1934) procedure using the dichromate wet oxidation method, total $\mathrm{N}$ was determined by micro-Kjeldahl digestion, followed by distillation and titration while the determination of other nutrients such as $\mathrm{P}, \mathrm{K}, \mathrm{Ca}$ and $\mathrm{Mg}$ was done using the wet digestion method based on 255-5 $\mathrm{mL}$ of $\mathrm{HNO}_{3}-\mathrm{H}_{2} \mathrm{SO}_{4}-\mathrm{HClO}_{4}$ acids. Phosphorus was measured calorimetrically by the molybdate blue method in an auto-analyzer, $\mathrm{K}$ by flame photometry, and $\mathrm{Ca}$ and $\mathrm{Mg}$ by atomic absorption spectrophotometer.

\section{Experimental Design and Agronomic Practices}

The conventional tillage operations which include ploughing and harrowing were carried out on the site. The experimental field of $11.5 \mathrm{~m}$ by $4 \mathrm{~m}$ was divided into three blocks each containing 8 beds giving a total of 24 beds on the site. Each bed size was constructed at $1 \mathrm{~m}$ by $1 \mathrm{~m}\left(1 \mathrm{~m}^{2}\right)$ having 16 
plants stand. The blocks were spaced $0.5 \mathrm{~m}$ apart for easy movement during cultural operations. Seeds were sowed two (2) weeks after application of soil amendments at a spacing of $30 \mathrm{~cm}$ by $30 \mathrm{~cm}$. Eight (8) treatments were used for the experiment which includes; control, NPK 20:10:10 (200kg/ha), $100 \%$ Cocoa pod ash (10t/ha), $100 \%$ Cocoa pod husk powder (10t/ha), $100 \%$ Cocoa pod ash (10t/ha) + $100 \%$ Cocoa pod husk powder(10t/ha), $100 \%$ Cocoa pod ash (10t/ha) + $50 \%$ Cocoa pod husk powder (5t/ha), $50 \%$ Cocoa pod ash $+100 \%$ Cocoa pod powder, $50 \%$ Cocoa pod ash $+50 \%$ Cocoa pod powder. Eight treatments were arranged in a randomized complete block design (RCBD) with three replications. Watering was done manually twice daily because the experiment was done almost at the end of the rainy season. Weeding was done manually when necessary. Staking vertically and horizontally was also done immediately at vine initiation. Harvesting of the cucumber fruits commenced at six (6) weeks after sowing when the fruits had turn deep green in color. Harvesting was done by handpicking of the matured fruits weekly. The following growth and yield data were collected; vine length, number of leaves, at 2, 4 and 6 weeks after sowing (WAS), while number of fruits per plant, fruit length $(\mathrm{cm})$, fruit girth $(\mathrm{cm})$ and fresh fruit weight $(\mathrm{kg})$ were determined at harvest.

\section{Statistical Analysis}

Data collected were subjected to Analysis of Variance (ANOVA) using SPSS (17) statistical package. Means squares that are significantly different were separated using Duncan multiple range test (DMRT) at 5\% level of probability.

\section{RESULTS AND DISCUSSION \\ Initial Soil Fertility Status and Chemical Properties of the Amendments Used for the Experiment}

Table 1 shows the chemical properties of the experimental field prior to planting. The results indicated that the soil used for the experiment was acidic and low in organic matter, total $\mathrm{N}$, available $\mathrm{P}$ and exchangeable $\mathrm{K}, \mathrm{Ca}$ and $\mathrm{Mg}$ which is unable to sustain crop yield without the addition of external input in this agro ecological zone for cropping according to the critical levels of $3.0 \%$ organic matter, $0.20 \% \mathrm{~N}, 10.0 \mathrm{mg} / \mathrm{kg}$ available $\mathrm{P}$, $0.16-0.20 \mathrm{cmol} / \mathrm{kg}$ exchangeable K, $2.0 \mathrm{cmol} / \mathrm{kg} \mathrm{Ca}$ and $0.40 \mathrm{cmol} / \mathrm{kg}$ exchangeable $\mathrm{Mg}$ recommended for crop production in ecological zones of Nigeria Akinrinde and Obigbesan, 2000). It was found that cocoa pod ash is high in $\mathrm{K}, \mathrm{Ca}$ and $\mathrm{Mg}$ but low in $\mathrm{N}$ and $\mathrm{P}$ while cocoa pod husk powder is high in $\mathrm{N}$ and $\mathrm{C} / \mathrm{N}$ ratio that could be easily decomposed, mineralized and release into the soil for crop use (Table 2).
Table 1: Soil physical and chemical characteristics of the experimental sites at $0-15 \mathrm{cmdepth}$

\begin{tabular}{ll}
\hline Parameters & Values \\
\hline Sand $(\%)$ & 76 \\
Silt $(\%)$ & 13 \\
Clay $(\%)$ & 11 \\
Textural class & Sandy loam \\
$\mathrm{pH}($ water $)$ & 5.25 \\
Organic matter (\%) & 2.24 \\
Total N (\%) & 0.16 \\
Available P $(\mathrm{mg} / \mathrm{kg})$ & 9.5 \\
Exchangeable K $\left(\mathrm{cmol} \mathrm{kg}^{-1}\right)$ & 0.14 \\
Exchangeable $\mathrm{Ca}\left(\mathrm{cmol} \mathrm{kg}^{-1}\right)$ & 2.0 \\
Exchangeable $\mathrm{Mg}\left(\mathrm{cmol} \mathrm{kg}^{-1}\right)$ & 0.36 \\
\hline
\end{tabular}

Effect of NPK Fertilizer with Sole and Integrated Forms of Cocoa Pod Ash and Cocoa Pod Husk Powder on Soil Chemical Properties

The results of the effect of NPK fertilizer with sole and integrated application of cocoa pod ash and cocoa pod husk powder on soil chemical properties are presented in Table 3. It shows that Cocoa pod ash and cocoa pod husk powder sole and in combination increased soil chemical properties compared with NPK fertilizer and the control. Using the values, treatments $100 \% \mathrm{CPA}+100 \%$ CPHP had the highest value of soil organic matter and $\mathrm{P}$, while NPK and control have the least value. Treatment $100 \%$ CPA + $100 \%$ CPHP and NPK had the highest value of $\mathrm{N}$, but treatment $100 \%$ $\mathrm{CPA}+100 \% \mathrm{CPHP}$ consistently gave the higher values of $\mathrm{K}$ and $\mathrm{Mg}$, treatments $100 \% \mathrm{CPA}+100$ $\%$ CPHP and $100 \%$ CPA + $100 \%$ CPHP had the highest value of $\mathrm{Ca}$. However, there were no significant differences in the $\mathrm{OM}$ and $\mathrm{N}$ values between $100 \% \mathrm{CPA}$ and $100 \% \mathrm{CPA}+50 \%$ CPHP showed no significant difference on the exchangeable calcium. The result indicated that 100 $\% \mathrm{CPA}+100 \% \mathrm{CPHP}$ and $100 \% \mathrm{CPA}+50 \%$ CPHP showed no significant difference on the exchangeable calcium, while controls have the least values of the soil chemical properties.

Effect of NPK Fertilizer with Sole and Integrated Forms of Cocoa Pod Ash and Cocoa Pod Husk Powder on Vine Length of Cucumber

Table 4 shows the effect of soil amendment on the vine length of cucumber. There were significant differences between among the treatments. At 2 WAP, treatment with $100 \% \mathrm{CPA}+100 \% \mathrm{CPHP}$ had the highest value of vine length, however, there were no significant differences between treatments with $100 \% \mathrm{CPA}$ and treatments with $100 \% \mathrm{CPHP}$ as compared with the control with the lowest value. At 4 WAP, treatments with $100 \%$ CPA $+100 \%$ $\mathrm{CPHP}$ and treatment with $100 \% \mathrm{CPHP}$ recorded the highest with statistical value while the control recorded the least value. At $6 \mathrm{WAP}$, treatments with $100 \% \mathrm{CPA}+100 \% \mathrm{CPHP}$ and $50 \% \mathrm{CPA}+$ $100 \%$ CPHP gave the highest value on vine length, although their values were statistically the same. 
It was also obtained that treatments with $100 \%$ $\mathrm{CPA}+50 \% \mathrm{CPHP}, 50 \% \mathrm{CPA}+50 \% \mathrm{CPHP}$ and $100 \%$ CPHP gave statistically similar values while the Control had the least value.

Effect of NPK Fertilizer with Sole and Integrated Forms of Cocoa Pod Ash and Cocoa Pod Husk Powder on Leave Number of Cucumber

Table 5 shows the effect of soil amendments on the number of leaves of Cucumber within the period of study. There were no significant differences at the 2WAP among the treatments. At 4 WAP, there were significant differences among the treatment; with $50 \% \mathrm{CPA}+50 \% \mathrm{CPHP}$ recorded the highest values of number of leaves. Treatments, $100 \%$ $\mathrm{CPA}+100 \% \mathrm{CPHP}, 100 \% \mathrm{CPA}+50 \% \mathrm{CPHP}$, $50 \% \mathrm{CPA}+100 \% \mathrm{CPHP}, 100 \% \mathrm{CPA}$ and $100 \%$ CPHP significantly performed the same having similar values on the number of leaves with the Control having the least values of leaves number in the experiment. At 6WAP, plots amended with 100 $\%$ CPA + $100 \%$ CPHP, $100 \%$ CPA +50 \% CPHP, $50 \% \mathrm{CPA}+100 \% \mathrm{CPHP}$ and $100 \%$ CPHP gave significantly higher leave number but statistically similar in their values. The results showed that plots treated with $50 \% \mathrm{CPA}+50 \%$ CPHP, $100 \%$ CPA and NPK on their part statistically had similar values, while the Control recorded the least value on the number of leaves of cucumber in the study.

Effect of NPK Fertilizer with Sole and Integrated Forms of Cocoa Pod Ash and Cocoa Pod Husk Powder on Number of Lateral Branches of Cucumber

Table 6 shows the effect of the soil amendments on the on the number of lateral branches of Cucumber within the period of study. At 2WAP, $100 \%$ CPA
$100 \%$ CPHP amended plots recorded the highest significant value of lateral branches, as plots treated with $100 \%$ CPA + $50 \%$ CPHP,50 \% CPA + 100 $\%$ CPHP, $50 \%$ CPA + $50 \%$ CPHP, $100 \%$ CPA, $100 \%$ CPHP and NPK had similar statistical values on the lateral branches, while control recorded the least value of lateral branches of cucumber. At 4WAP, $50 \% \mathrm{CPA}+50 \% \mathrm{CPHP}$ amended plots recorded the highest significant value of lateral branches, while plots treated with $100 \% \mathrm{CPA}+100 \% \mathrm{CPHP}, 100 \% \mathrm{CPA}+50$ $\%$ CPHP, $50 \%$ CPA $+100 \%$ CPHP, $100 \%$ CPA and $100 \%$ CPHP had similar statistical value on number of lateral branches, while control recorded the least value of lateral branches of cucumber. At $6 \mathrm{WAP}$, there were no significant different among the amended plots, but treatment with $100 \% \mathrm{CPA}$ $+50 \%$ CPHP had the highest statistical values as compared with to the control.

Effect of NPK Fertilizer with Sole and Integrated Forms of Cocoa Pod Ash and Cocoa Pod Husk Powder on Mean Yield Parameters of Cucumber The result of the effect of NPK fertilizer with sole and integrated application of cocoa pod ash and cocoa pod husk powder on mean yield parameters of cucumber was presented in table 7. Sole application of cocoa pod ash or cocoa pod husk powder and integration of both increased the yield parameters of cucumber (fruit number, fruit length, fruit girth, fruit weight and total yield) significantly higher compared with no application of any amendment (control). Treatments with $100 \% \mathrm{CPA}$ $+100 \%$ CPHP and $100 \% \mathrm{CPA}+50 \%$ CPHP recorded the highest values on all the yield parameters.

Table 2: Nutrient composition of cocoa pod ash and cocoa pod husk powder

\begin{tabular}{llllllll}
\hline Nutrient & $\mathrm{N}(\%)$ & $\mathrm{P}(\%)$ & $\mathrm{K}(\%)$ & Organic C $(\%)$ & $\mathrm{C} / \mathrm{N}$ & $\mathrm{Ca}(\%)$ & $\mathrm{Mg}(\%)$ \\
\hline $\begin{array}{l}\text { Cocoa pod ash } \\
\begin{array}{l}\text { Cocoa pod husk } \\
\text { powder }\end{array}\end{array}$ & 1.27 & 1.22 & 14.01 & 16.97 & 13.36 & 3.33 & 2.1 \\
\hline
\end{tabular}

Table 3: Effect of NPK fertilizer with sole and integrated forms of cocoa pod ash and cocoa pod husk powder on soil chemical properties

\begin{tabular}{|c|c|c|c|c|c|c|c|}
\hline Treatments & $\mathrm{OM}(\%)$ & $\mathrm{N}(\%)$ & $\mathrm{P}\left(\mathrm{mg} \mathrm{kg}^{-1}\right)$ & $\mathrm{K}\left(\mathrm{cmol} \mathrm{kg}^{-1}\right)$ & $\mathrm{Ca}\left(\mathrm{cmol} \mathrm{kg}^{-1}\right)$ & $\mathrm{Mg}\left(\mathrm{cmol} \mathrm{kg}^{-1}\right)$ & $\mathrm{pH}$ \\
\hline CONTROL & $2.10^{\mathrm{d}}$ & $0.15^{\mathrm{c}}$ & $8.1^{\mathrm{d}}$ & $0.13^{\text {cd }}$ & $1.9^{\mathrm{d}}$ & $0.33^{\mathrm{c}}$ & $5.80^{\mathrm{d}}$ \\
\hline NPK & $2.13^{\mathrm{d}}$ & $0.40^{\mathrm{a}}$ & $8.2^{\mathrm{d}}$ & $0.18^{\mathrm{c}}$ & $2.2^{\mathrm{d}}$ & $0.31^{\mathrm{c}}$ & $5.81^{\mathrm{d}}$ \\
\hline $100 \%$ CPA & $4.15^{\mathrm{ab}}$ & $0.34^{\mathrm{ab}}$ & $9.1^{\mathrm{c}}$ & $0.17^{\mathrm{c}}$ & $2.9^{\mathrm{c}}$ & $0.44^{\mathrm{b}}$ & $8.73^{\mathrm{ab}}$ \\
\hline $100 \%$ СРHР & $2.58^{\mathrm{c}}$ & $0.16^{\mathrm{c}}$ & $11.4^{\mathrm{ab}}$ & $0.87^{\mathrm{b}}$ & $2.0^{\mathrm{d}}$ & $0.34^{\mathrm{c}}$ & $6.79^{c}$ \\
\hline $100 \% \mathrm{CPA}+100 \% \mathrm{CPHP}$ & $4.86^{\mathrm{a}}$ & $0.42^{\mathrm{a}}$ & $11.7^{\mathrm{a}}$ & $1.44^{\mathrm{a}}$ & $4.10^{\mathrm{a}}$ & $0.50^{\mathrm{a}}$ & $8.84^{\mathrm{a}}$ \\
\hline $100 \% \mathrm{CPA}+50 \% \mathrm{CPHP}$ & $4.36^{\mathrm{ab}}$ & $0.36^{\mathrm{ab}}$ & $11.2^{\mathrm{ab}}$ & $1.17^{\mathrm{ab}}$ & $4.0^{\mathrm{a}}$ & $0.46^{\mathrm{ab}}$ & $8.22^{\mathrm{a}}$ \\
\hline $50 \% \mathrm{CPA}+100 \% \mathrm{CPHP}$ & $3.20^{\mathrm{bc}}$ & $0.26^{\mathrm{b}}$ & $10.5^{b}$ & $0.47^{\mathrm{bc}}$ & $3.40^{\mathrm{ab}}$ & $0.44^{\mathrm{ab}}$ & $8.28^{\mathrm{b}}$ \\
\hline $50 \% \mathrm{CPA}+50 \% \mathrm{CPHP}$ & $3.7^{\mathrm{b}}$ & $0.26^{\mathrm{b}}$ & $9.8^{\mathrm{bc}}$ & $0.44^{\mathrm{bc}}$ & $3.30^{\mathrm{ab}}$ & $0.40^{\mathrm{b}}$ & $7.88^{b c}$ \\
\hline
\end{tabular}

Means in a column under any given treatment followed by the same letter do not differ significantly at 0.05 level of probability using the Duncan's Multiple Range Test (DMRT) 
Table 4: Effect of NPK fertilizer with sole and integrated forms of cocoa pod ash and cocoa pod husk powder on vine length of cucumber

\begin{tabular}{llll}
\hline Treatment & $2 \mathrm{WAP}$ & $4 \mathrm{WAP}$ & $6 \mathrm{WAP}$ \\
\hline CONTROL & $2.99^{\mathrm{c}}$ & $6.95^{\mathrm{c}}$ & $11.23^{\mathrm{c}}$ \\
NPK & $3.21^{\mathrm{bc}}$ & $7.79^{\mathrm{bc}}$ & $14.46^{\mathrm{c}}$ \\
$100 \%$ CPA & $3.54^{\mathrm{b}}$ & $9.55^{\mathrm{b}}$ & $16.12^{\mathrm{b}}$ \\
$100 \%$ CPHP & $3.55^{\mathrm{b}}$ & $11.32^{\mathrm{a}}$ & $20.53^{\mathrm{ab}}$ \\
$100 \%$ CPA + $100 \%$ CPHP & $4.25^{\mathrm{a}}$ & $11.69^{\mathrm{a}}$ & $23.20^{\mathrm{a}}$ \\
$100 \%$ CPA + 50\% CPHP & $3.33^{\mathrm{bc}}$ & $10.28^{\mathrm{ab}}$ & $21.62^{\mathrm{ab}}$ \\
$50 \% \mathrm{CPA}+100 \%$ CPHP & $3.94^{\mathrm{ab}}$ & $10.99^{\mathrm{a}}$ & $21.87^{\mathrm{a}}$ \\
$50 \%$ CPA + 50\% CPHP & $3.97^{\mathrm{ab}}$ & $12.01^{\mathrm{a}}$ & $21.02^{\mathrm{ab}}$ \\
\hline
\end{tabular}

Means in a column under any given treatment followed by the same letter do not differ significantly at 0.05 level of probability using the Duncan's Multiple Range Test (DMRT)

Table 5: Effect of NPK fertilizer with sole and integrated forms of cocoa pod ash and cocoa pod husk powder on number of leaves

\begin{tabular}{llll}
\hline Treatment & $2 \mathrm{WAP}$ & $4 \mathrm{WAP}$ & $6 \mathrm{WAP}$ \\
\hline CONTROL & $3.85^{\mathrm{a}}$ & $5.65^{\mathrm{b}}$ & $6.58^{\mathrm{b}}$ \\
NPK & $4.01^{\mathrm{a}}$ & $5.83^{\mathrm{b}}$ & $7.94^{\mathrm{ab}}$ \\
$100 \% \mathrm{CPA}$ & $4.22^{\mathrm{a}}$ & $6.27^{\mathrm{ab}}$ & $8.44^{\mathrm{ab}}$ \\
$100 \% \mathrm{CPHP}$ & $3.88^{\mathrm{a}}$ & $6.33^{\mathrm{ab}}$ & $9.36^{\mathrm{a}}$ \\
$100 \% \mathrm{CPA}+100 \%$ CPHP & $4.33^{\mathrm{a}}$ & $6.60^{\mathrm{ab}}$ & $10.36^{\mathrm{a}}$ \\
$100 \% \mathrm{CPA}+50 \%$ CPHP & $4.13^{\mathrm{a}}$ & $6.36^{\mathrm{ab}}$ & $10.15^{\mathrm{a}}$ \\
$50 \% \mathrm{CPA}+100 \%$ CPHP & $4.27^{\mathrm{a}}$ & $6.27^{\mathrm{ab}}$ & $9.42^{\mathrm{a}}$ \\
$50 \% \mathrm{CPA}+50 \% \mathrm{CPHP}$ & $4.11^{\mathrm{a}}$ & $6.99^{\mathrm{a}}$ & $9.24^{\mathrm{ab}}$ \\
\hline
\end{tabular}

Means in a column under any given treatment followed by the same letter do not differ significantly at 0.05 level of probability using the Duncan's Multiple Range Test (DMRT)

Table 6: Effect of NPK fertilizer with sole and integrated forms of cocoa pod ash and cocoa pod husk powder on number of lateral branches

\begin{tabular}{|c|c|c|c|}
\hline Treatment & 2WAP & 4WAP & 6WAP \\
\hline CONTROL & $3.49^{b}$ & $5.71^{b}$ & $6.42^{\mathrm{a}}$ \\
\hline NPK & $3.73^{\mathrm{ab}}$ & $5.83^{\mathrm{b}}$ & $7.05^{\mathrm{a}}$ \\
\hline $100 \% \mathrm{CPA}$ & $3.88^{\mathrm{ab}}$ & $6.27^{\mathrm{ab}}$ & $7.55^{\mathrm{a}}$ \\
\hline $100 \%$ CPHP & $3.73^{\mathrm{ab}}$ & $6.33^{\mathrm{ab}}$ & $8.33^{\mathrm{a}}$ \\
\hline $100 \% \mathrm{CPA}+100 \% \mathrm{CPHP}$ & $4.11^{\mathrm{a}}$ & $6.44^{\mathrm{ab}}$ & $8.98^{\mathrm{a}}$ \\
\hline $100 \% \mathrm{CPA}+50 \% \mathrm{CPHP}$ & $3.93^{\mathrm{ab}}$ & $6.30^{\mathrm{ab}}$ & $9.06^{\mathrm{a}}$ \\
\hline $50 \% \mathrm{CPA}+100 \% \mathrm{CPHP}$ & $3.88^{\mathrm{ab}}$ & $6.27^{\mathrm{ab}}$ & $8.12^{\mathrm{a}}$ \\
\hline $50 \% \mathrm{CPA}+50 \% \mathrm{CPHP}$ & $4.00^{\mathrm{ab}}$ & $6.88^{\mathrm{a}}$ & $7.70^{\mathrm{a}}$ \\
\hline
\end{tabular}

Means in a column under any given treatment followed by the same letter do not differ significantly at 0.05 level of probability using the Duncan's Multiple Range Test (DMRT)

Table 7: Effect of NPK fertilizer with sole and integrated forms of cocoa pod ash and cocoa pod husk powder on mean yield parameters of cucumber

\begin{tabular}{|c|c|c|c|c|c|}
\hline Treatments & Fruit No $\left(\mathrm{n} \mathrm{ha}^{-1}\right)$ & Fruit Length $(\mathrm{cm})$ & Fruit Girth $(\mathrm{cm})$ & $\begin{array}{l}\text { Fruit } \\
\text { Weight }(\mathrm{kg})\end{array}$ & Yield $\left(\mathrm{t} \mathrm{ha}^{-1)}\right.$ \\
\hline CONTROL & $5.05^{\mathrm{d}}$ & $15.00^{\mathrm{d}}$ & $4.67^{d}$ & $1.39^{\mathrm{d}}$ & $24881.46^{\mathrm{d}}$ \\
\hline NPK & $8.76^{\mathrm{b}}$ & $15.84^{\mathrm{ab}}$ & $5.18^{\mathrm{ab}}$ & $1.83^{\mathrm{b}}$ & $35278.33^{\mathrm{b}}$ \\
\hline $100 \% \mathrm{CPA}$ & $8.49^{c}$ & $15.77^{\mathrm{b}}$ & $5.15^{\mathrm{b}}$ & $1.85^{\mathrm{b}}$ & $32218.46^{\mathrm{c}}$ \\
\hline $100 \%$ CPHP & $8.29^{\mathrm{d}}$ & $15.66 b^{c}$ & $5.14^{\mathrm{b}}$ & $1.80^{\mathrm{bc}}$ & $32178.33^{\mathrm{c}}$ \\
\hline $100 \%$ CPA $100 \% \mathrm{CPHP}$ & $11.55^{\mathrm{a}}$ & $15.92^{\mathrm{a}}$ & $5.44^{\mathrm{a}}$ & $2.34^{\mathrm{a}}$ & $398533.18^{\mathrm{a}}$ \\
\hline $100 \% \mathrm{CPA}+50 \% \mathrm{CPHP}$ & $11.35^{\mathrm{ab}}$ & $15.85^{\mathrm{ab}}$ & $5.42^{\mathrm{a}}$ & $2.03^{\mathrm{ab}}$ & $35353.25^{\mathrm{b}}$ \\
\hline $50 \% \mathrm{CPA}+100 \% \mathrm{CPHP}$ & $8.79^{\mathrm{b}}$ & $15.35^{\mathrm{c}}$ & $5.24^{\mathrm{ab}}$ & $1.83^{\mathrm{b}}$ & $32411.37^{\mathrm{c}}$ \\
\hline $50 \% \mathrm{CPA}+50 \% \mathrm{CPHP}$ & $8.79^{b}$ & $15.34^{\mathrm{c}}$ & $4.87^{\mathrm{c}}$ & $1.57^{\mathrm{c}}$ & $32248.67^{\mathrm{c}}$ \\
\hline
\end{tabular}

Means in a column under any given treatment followed by the same letter do not differ significantly at 0.05 level of probability using the Duncan's Multiple Range Test (DMRT)

\section{DISCUSSION}

The analysis of cocoa pod ash and cocoa pod husk powder showed that they were composed of $\mathrm{N}, \mathrm{P}, \mathrm{K}, \mathrm{Ca}$, and $\mathrm{Mg}$. The increases in soil nutrients content can be adduced to the soil amendment applied which is consistent with the findings of Ayeni (2008), and Odedina et al (2003) that cocoa pod ash and cocoa pod husk powder increased soil organic matter, N, P, K,
$\mathrm{Ca}$, and $\mathrm{Mg}$. It was also noted that Cocoa pod ash or cocoa pod powder sole and their integration increased growth and yield parameters of cucumber compared with NPK and no application of either cocoa pod ash or cocoa pod powder (Control). This showed that the soil in the area is deficient of essential nutrients importantly those that improve 
growth and development of cucumber. This is supported by the result of the initial fertility status of the soil which showed low organic matter content and other soil nutrients. Treatment $100 \% \mathrm{CPA}+100 \%$ CPHP have the highest values of organic matter, $\mathrm{N}, \mathrm{P}, \mathrm{K}$, $\mathrm{Ca}, \mathrm{Mg}$, and $\mathrm{pH}$. This can be adduced to the highest nutrient supplied by $100 \% \mathrm{CPA}$ and $100 \%$ CPHP. However, treatments $100 \%$ $\mathrm{CPA}+50 \% \mathrm{CPHP}$ and $100 \% \mathrm{CPA}+100 \%$ CPHP had similar values on cucumber growth and yield parameters. This simply connotes that $100 \% \mathrm{CPA}+50 \% \mathrm{CPHP}$ (application of Cocoa pod ash at 10t/ha and Cocoa pod powder at $5 \mathrm{t} / \mathrm{ha}$ ) is equally adequate for growth and yield of cucumber. This study showed that cocoa pod ash and cocoa pod husk powder which is apparently a waste product of cocoa and a farm waste could be used to increase availability of $\mathrm{N}, \mathrm{P}, \mathrm{K}, \mathrm{Ca}$, and $\mathrm{Mg}$ in soil and their uptake by cucumber thereby leading to enhanced growth and yield performance of the cucumber plant which agree with the findings of Nwite et al (2013) that organic amendment have the potential of increasing yield of crop..

\section{CONCLUSION}

The results of this study revealed that soil chemical properties, vegetative parameters and yield component were all significantly increased with sole or integrated application of cocoa pod ash and cocoa pod husk powder. Cocoa pod ash applied at $10 \mathrm{t} / \mathrm{ha}$ with lower level of cocoa pod husk powder at $5 \mathrm{t} / \mathrm{ha}$ was more effective in the release of soil nutrient as well as yield than when highest level of cocoa pod ash and highest level of cocoa pod powder are been integrated. Therefore he integration of cocoa pod ash at $10 \mathrm{t} / \mathrm{ha}$ with $5 \mathrm{t} / \mathrm{ha}$ cocoa pod husk powder fertilizer is recommended for cropping of cucumber in the Southern Guinea Savannah zone of Nigeria.

\section{REFERENCES}

Adu-Dapaah H.K., Cobbinah J. and Asare E.O. (1994). Effect of cocoa pod ash on the growth of maize. J. Agric. Sci., 122 31-33

Ajayi C.A., Awodun M.A. and Ojeniyi S.O. (2007). Comparative effect of Cocoa Husk ash and NPK fertilizer on Soil and Root nutrients content and growth of Kola Seedlings. International Journal of Soil Science 2 (2), 148 - 153

Akanbi O.S., Ojeniyi S.O., Famaye A.O., Ipinmoroti R.R., Oloyede A.A., Oyewumi I.K., Ayegbonyin K., Adejobi K. B. and Idrisu M. (2014). Soil nutrients and cocoa seedling performance as influenced by plant residue ash and NPK fertilizer addition on a depleted soil in Ibadan, south western, Nigeria. Int. Res. J. Agric. Sci. Soil Sci. 4 (1), 1 - 4
Akinrinde E.A. and Obigbesan G.O. (2000). Evaluation of the fertility status of selected soils for crop production in five ecological zones of Nigeria. In: Babalola O. (ed.). Proceedings of the $26^{\text {th }}$ Annual Conference of Soil Science Society of Nigeria; 2000 Oct 30Nov 3; Ibadan, Nigeria., 279-288

Anderson J.M. and Ingram J.S.I. (1993). Tropical Soil Biology and Fertility: A Handbook Of Methods. Wallingford (UK): CAB International. $221 \mathrm{pp}$

Ayeni L.S. (2008). Integrated application of cocoa pod ash and NPK fertilizer on soil chemical properties and yield of tomato. AmericanEurasian Journal of Sustainable Agriculture, 2 (3), 333-337

Ayeni L.S. Adetunji M.T. Ojeniyi S.O. Ewulo B.S. and Adeyemo A.J. (2008). Comparative and Cumulative Effect of Cocoa Pod Husk Ash and Poultry Manure on Soil and Maize Nutrient Contents and Yield, Am.-Eurasian J. Sustain. Agric., 2 (1), 92-97

Ayoola O.T. and Adeniran O.N., (2006). Influence of poultry manure and NPK fertilizer on yield and yield components of crops under different cropping systems in South West Nigeria. African Journal of Biotechnol., 5, 1336-1392

Chaterjee B.P., Ghanti U., and Thapa P., (2005). Effect of organic nutrition in spro broccoli (Brassic oleraceae var.italica plenck), Vegetable Science, 33 (1), 51-54

Eifediyi E.K., Ahamefule H.E. and Remison S.U. (2015). Effects of neem seed cake on the growth and yield of okra (Abelmoschus esculentus (L.) Moench) in Ilorin, north central Nigeria. Agro-Science, 12 (2), 20-27. DOI: 10.4314/as.v12i2.3.

Egunjobi O.A. (1975). On the possible utilization of discarded cocoa pod husk as fertilizer and nematicide. Proceedings of the 5th International Cocoa Research Conference, September 1-9, 1975, Ibadan, pp: 541-547

Follett R.F. (2001).Soil management concepts and carbon sequestration in cropland soils. Soil Tillage Res., 61, 77-92

Gee G.W. and Or D. (2002). Particle-size analysis. In: Dane J.H., \& Topp G.O. (Eds.), Methods of Soil Analysis, Part 4: Physical Methods. Soil Science Society of America, No. 5, Madison, Wisconsin, pp. 255-293

Harper F. (1983). Principles of Arable Crop Production. Blackwell Science Ltd.UK 8:336

Idem N.U.A., Ikeh A.O., Asikpo N.S. and Udoh E.I. (2012). Effect of organic and inorganic fertilizer on growth and yield of fluted pumpkin (Telfaria occidentialis, Hook f.) in Uyo, Akwa Ibom State, Nigeria. Journal of Agriculture \& Social Research (JASR), 12 (2)

Lower R.L. and Edwards M.D. (1986). Cucumber breeding In: M.J. Basset, (ed.). Breeding Vegetables Crops. Westport, Connecticut USA: AVI Publishing Co pp. 173-203

Muruganantham N., Solomon S. and Senthamilselvi M.M. (2016). Anti-oxidant and anti-inflammatory activity of Cucumis sativas (Cucumber) flowers. International Journal of Pharmaceutical Sciences \& Research, 7 (4), 1740-1745 
Nelson D.W., and Sommers L.E. (1996). Total carbon, organic carbon and organic matter. In Methods of Soil Analysis, Part 3. 2nd edn, 9611010. (Ed. D. L. Sparks) SSSA Book Series No. 5, ASA and SSSA, Madison, WI., USA

Nwite J.C., Keke C.I., Obalum S.E., Essien J.B., Anaele M.U. and Igwe, C.A. (2013): Organomineral amendment options for enhancing soil fertility and nutrient composition and yield of fluted pumpkin. International Journal of Vegetable Science, 19 (2), 188-199

Obatulu C.R. and Agboola A.A. (1993). The potential of Siam weed (Chromolaena odorata) as a source of organic matter for soils in the humid tropics. - In: Mulongoy, K., Merckx, R. (eds.) Soil organic matter dynamics and sustainability of Tropical Agriculture, Proceedings of an International Sympos ium Leuven Belgium, 4-6 November. pp 89-99. John Wiley and Sons Ltd. Chiche ster, England
Ogbonna P.E. (2008). Effect of combined application of organic and inorganic fertilizers on fruit yield of eggplant (Solanum melongena). Pro. 42nd Annual conf. Agricultural Society of Nigeria (ASN) October 19-23 p. $236-250$

Okalebo J.R., Gathua K.W. and Woomer P.L., (2002). Laboratory Methods of Soil and Plant Analysis. A Working Manual. 2nd edn. TSBFCIAT, SACRED Africa, KARI, Soil Science Society of East Africa, Nairobi, Kenya, p. 128

Tisdale S.A and Nelson W.L. (1975). Soil Fertility and Fertilizers. Macmillan Publ. Co. Inc. 3rd edn.New York. p. 694.Tomato and Pepper. Nigerian Journal of Soil Science, (13), 61-67

Walkley A., and Black I.A., (1934). An examination of the degtjareff method for determining soil organic matter and a proposed modification of the chromic acid titration method. Soil Sci., 37, 29-38

Wessel Marius and Quist-Wessel P.M (2015). Cocoa production in West Africa, a review and analysis of recent developments. NJAS Wageningen Journal of Life Sciences. 74. 10.1016/j.njas.2015.09.001 